\title{
Process contaminants in battered and breaded foods prepared at public food service establishments
}

\author{
Marta Mesías, Cristina Delgado-Andrade, Francisco J Morales
}

Instituto de Ciencia y Tecnología de Alimentos y Nutrición (ICTAN-CSIC), Madrid, Spain

\begin{abstract}
Acrylamide is a process contaminant already regulated in Europe whereas the toxicological effects of certain heat-induced furan derivatives such as hydroxymethylfurfural (HMF) and furfural are still under revision. Acrylamide, HMF and furfural content were evaluated in 113 coated fried foods provided by food services (restaurants and school canteens). Sampling included battered and breaded foods intended for frying and were grouped according to meat-products (ham \& cheese, chicken nuggets), fish-products (fish sticks, fish fillets), seafood (squid rings), vegetables (onion rings), and doughs (croquettes). Acrylamide ranged between 23.8 and $130.4 \mu \mathrm{g} / \mathrm{kg}$, HMF between $0.1 \mathrm{I}$ and $16.07 \mathrm{mg} / \mathrm{kg}$, and furfural between $0.0 \mathrm{I}$ and $1.04 \mathrm{mg} / \mathrm{kg}$. Presence of these compounds was mostly restricted to the outer part of foods (coating material), since browning reactions are sped up in the crust. Onion rings showed a significantly higher concentration than the other samples being studied. Home-style (freshly made) chicken nuggets exhibited significantly lower acrylamide content than frozen par-fried nuggets from an industrial source. This finding suggests that increasing the complexity of the formulation of the coating through the introduction of ingredients or additives aimed at improving palatability might lead to the development of heat induced process contaminants. As a consequence, the increase of harmful compounds during thermal treatment of coated food should be carefully considered during the industrial formulation of coatings. Although the recent Regulation 2017/2158 for acrylamide does not mention specific values or mitigation strategies for coated foods, its contribution to daily acrylamide exposure within the population must not be dismissed. This study involves the first systematic prospective evaluation of process contaminants in real operative conditions at food services in Spain.
\end{abstract}

\section{INTRODUCTION}

Battering and breading are culinary operations widely applied to fish, seafood, cheese, vegetables, poultry and other meat products during home cooking, and in catering services and the food industry. These techniques improve the shelf life, crispness, texture, appearance, palatability and flavor of fried and baked foods, since the final product is characterized by a crispy outer layer with a tender, moist and juicy interior (Tamsen, Soltanizadeh, \& Shekarchizadeh, 2018). In short, the final structure depends on the water content, size of the piece, composition and particle size of the coating material, and processing conditions (Albert, Salvador, Hough, \& Fiszman, 2013).

Although battered and breaded foods have traditionally been present in most cultures, changes to the dietary habits of the young-adult population conditioned by socioeconomic circumstances have led to an increase in their consumption. The appearance of precooked, ready-to eat and take away battered and breaded products in the food market has made these products a quick and convenient meal solution at moderate cost (Gilbert \& Khokhar, 2008; Varela-Moreiras et al., 2010; AESAN, 2019). For these reasons, the annual consumption of coated foods has reached values exceeding nine hundred tons in Europe, Japan, and Oceania (Tamsen et al., 2018). In Spain, the NAOS strategy (National Strategy for Nutrition, Physical Activity and Prevention of Obesity) has targeted reductions in the consumption of fatty foods due to their high caloric content (AECOSAN, 2005). However, the inclusion in schools menus of fresh or precooked battered and breaded products several times a month is a common practice. This is especially important in the case of younger 
populations, since $36.4 \%$ of Spanish students undertaking early childhood education and $29.4 \%$ of primary school children consume the main meal of the day at school (Villadiego \& Castro, 2018).

The composition of coated foods and the processing conditions during frying promote rapid development of non-enzymatic browning reactions. This results in the formation of process contaminants, such as acrylamide, and emerging process contaminants, such as hydroxymethylfurfural (HMF) and furfural (Capuano \& Fogliano, 20II; Morales, 2008; Paleologos \& Kontoninas, 2007; Pérez-Palacios, Petisca, Henriques, \& Ferreira, 20I3). These undesirable compounds are mainly located in the coating and their occurrence depends on different factors, such as the coating composition and severity of the thermal treatment (Morales \& Arribas-Lorenzo, 2008).

The European Food Safety Authority (EFSA) has confirmed that the presence of acrylamide in food is a public health concern requiring continued efforts to reduce its exposure (EFSA, 20I5). The recent Regulation $2017 / 2158$ (EC, 2017) on benchmark levels for the reduction of the presence of acrylamide in foods and the acrylamide toolbox compiled by Food Drink Europe (FDE, 2019) do not mention reference values or specific mitigation strategies for battered and breaded products. HMF and furfural have been extensively applied as heat-induced chemical indexes for monitoring the thermal damage of food. However, these furan derivatives are under evaluation as emerging processing contaminants since evidence produced from animal-based studies suggests that HMF may have diverse harmful effects on human health. These potential effects include carcinogenicity, neoplasic transformation, hepatotoxicity and nephrotoxicity (Lee et al., 2019), and genotoxic and mutagenic effects derived through the metabolism product sulphoxymethylfurfural (Glatt, Schneider, \& Liu, 2005; Høie et al., 20I5). On the other hand, furfural may also lead to hepatotoxicity (EFSA, 2005).

The composition of a coating usually consists of flour dipped in water. This sometimes incorporates a leavening agent which promotes its expansion during frying, turning it into a tempura. In contrast, in the case of breaded foods, flour-based breadcrumbs are applied over an adhesion layer. The composition of coatings are increasing in complexity in order to meet consumer expectations for convenience, appearance and palatability. Nowadays, coating material includes starches (including potato starch), leavening agent, flavorings, seasonings, shortenings and oils, salt, hydrocolloids and gums, eggs, and milk products in order to improve product color, texture, and water-holding capacity, and reduce oil-uptake (Brannan et al., 20I4; Loewe, 20I I; Mallikarjunan, Ngadi, \& Chinnan, 2010). Indeed, the relationship of the coating material of coated cooked foods with frying oil, and the texture and reduction of oil-uptake has been extensively investigated (Albert et al., 20I3; Alburquerque, Oliveira, Sanches-Silva, Bento, \& Costa, 2016; Lazarick, Aladedunye, \& Przybylski, 20I4; Maskat \& Kerr, 2002; Suderman, 20II). On the other hand, the potential toxicological side effects have been scarcely addressed (Pérez-Palacios, Petisca, Henriques, \& Ferreira, 20I3).

Due to the increasing consumption of battered and breaded foods in different population groups and the toxicological relevance of some compounds formed during deep-fat frying, the aim of this investigation was to evaluate acrylamide, HMF and furfural levels in battered and breaded products included on the menus of chain restaurants and school canteens. Coated fried foods were grouped as industrial (frozen par-fried foods) and home-style (freshly prepared) foods, as well as according to the type of coating (breaded and battered) in order to get more insight into the influence of the composition of the coating material on the formation of process contaminants. This study involves the first systematic prospective evaluation of these compounds in real operating conditions at food services in Spain.

\section{MATERIALS AND METHODS}




\section{Chemicals and reagents}

HMF, furfural, potassium hexacyanoferrate (II) trihydrate (98\%, Carrez-I) and zinc acetate dehydrate (> 99\%, Carrez-II) were obtained from Sigma (St. Louis, USA). I3C3-labelled acrylamide ( $99 \%$ isotopic purity) was obtained from Cambridge Isotope Laboratories (Andover, MA, USA). Acetonitrile, formic acid (98\%) and methanol (Highperformance liquid chromatography (HPLC) grade) were obtained from Merck (Darmstadt, Germany). Deionized water was obtained from a Milli-Q Integral 5 water purification system (Millipore, Billerica, MA, USA). All other chemicals, solvents and reagents were of analytical grade.

\section{Study design}

Five brands of chain restaurants operating under a trademark and twenty-eight primary school canteens were recruited. Three different food service establishments for each of the five restaurants participated. All establishments came from the province of Madrid (Spain). Sampling at each establishment took place on two different days (day-I, day-2), within a period of at least 3 weeks. This time interval ensured the use of different sets of coated foods. Two different time-points during the same day were selected for sampling (lunch, dinner) in order to evaluate the contribution of food handlers. Primary schools were selected from three Spanish regions located in the center (Madrid), mid-east (Castilla La Mancha) and east of the country (Valencia). Meals are prepared daily in the canteens for primary school students aged between 6 and 12 years.

Food operators in both restaurants and school canteens did not receive instructions for coated food preparation (manipulation, frying appliance, frying temperature or oil to be used, food/oil ratio and endpoint). Internal protocols intended for frying and established by the restaurants and school canteens were followed in order to reflect usual practice. In this way, a randomized and large scenario of practices for the preparation of coated deep-fried foods at public food services was considered. All food handlers were unaware of the purpose of the research and were not informed in detail about the goal of the investigation. This served to avoid any influence on their normal behavior during the experiment. They provided passive consent prior to completing the study and did not receive any incentives for their participation. The study was conducted from May to June 2017.

\section{Sampling}

The suitable sample size for the study was statistically estimated. Restaurants and school canteens received a 'sampling kit' containing a guide with instructions for sampling according to the study design. Properly coded containers were also provided to dispatch foods. In the case of restaurants, each one collected one sample at two different time points in the same day. This was done on two different days at three different establishments ( $n=60$ samples). For school canteens, sampling depended on the menu scheduled for schoolchildren during the period of data collection. Sampling was, therefore, not as systematic as it was for restaurants. Once this information was obtained, one or two samples of coated deep-fried food per school were collected $(n=53$ samples). Once cooled, coated deep-fried foods were placed in an airtight freezer bag, frozen and couriered to the lab. Upon reception, samples were stored at $-20^{\circ} \mathrm{C}$ until analysis.

\section{Samples}

Samples were classified according to food type (meat, fish, seafood, vegetables and dough). Seven types of coated foods were collected, these being ham \& cheese (breaded, $n=16$ ), chicken nuggets (breaded, $n=42$ ), fish sticks (breaded, $n=14$ ), fish fillets (breaded, $n=19$ ), squid rings (breaded, $n=2$ ), onion rings (breaded, $n$ $=6$; battered $n=6$ ), and croquettes (breaded, $n=8$ ). Table SI describes the number and type of samples provided by the restaurants and school canteens. Samples were also classified as industrial (frozen par-fried foods) or home-style (freshly prepared battered and breaded foods) foods. Each sample batch was separated 
into two groups in order to analyze the food overall and its outer part. The coating was manually removed and the amount of coating adhered to the sample after frying was calculated as the ratio of the weight of the coating relative to the weight of the coated sample, multiplied by 100 . Both the coating material and the entire food were weighed and crushed for analysis. The composition of the different layers of the coating material is unknown.

\section{Acrylamide determination by liquid chromatography-electrospray ionization-tandem mass spectrometry}

Acrylamide was determined in fried samples (entire food and crust) as described by Mesias and Morales (20I5). The recovery rate of samples spiked with acrylamide was between 90 and 106\%. Relative standard deviations (RSD) indicating the precision, repeatability and reproducibility of analyses were calculated as $2.8 \%, 1.2 \%$ and $2.5 \%$, respectively. The limit of quantitation (LOQ) was set at $15 \mu \mathrm{g} / \mathrm{kg}$, complying with the performance criteria set by EU Regulation 2017/2158. The accuracy of results was demonstrated for potato crisps and precooked French fries in four proficiency tests conducted by the Food Analysis Performance Assessment Scheme (FAPAS) program, yielding a z-score of -0.2 (Test 307I, Feb-March 20I7) -0.3 (Test 3080, Feb-March 20I8), 0.0 (Test 3085, Sep-Oct 2018) and 0.3 (Test 3089, Feb-2019). Results for acrylamide were expressed as $\mu g / \mathrm{kg}$ of sample (fresh weight). Analysis was done in triplicate.

\section{HMF and furfural determination by HPLC-Diode array detector (DAD)}

HMF and furfural content was determined in fried samples (entire food and crust) by HPLC as described by Mesias, Holgado, Marquez-Ruiz, and Morales (20I5). Analysis was conducted with a Shimadzu HPLC system (Kyoto, Japan) equipped with an LC-20AD pump, an SIL-IOADvp autosampler, a CTO-IOASVP oven, and an SPD-M20A diode array detector. Chromatographic separation was carried out on a Mediterranean Sea ODS$2(250 \times 4.0 \mathrm{~mm}, 5 \mu \mathrm{m}$, Tecknokroma, Barcelona, Spain). The mobile phase was a mixture of acetonitrile in water $(5 \mathrm{~mL} / 100 \mathrm{~mL})$ at a flow rate of $\mathrm{I} \mathrm{mL} / \mathrm{min}$ under isocratic conditions. Running time was $20 \mathrm{~min}$, the diode-array detector was set at $280 \mathrm{~nm}$, and $20 \mu \mathrm{L}$ of the extract was injected. HMF and furfural were quantified using the external standard method with pure standards. The LOQ was set at $0.1 \mathrm{mg} / \mathrm{kg}$ for both $\mathrm{HMF}$ and furfural. Analyses were done in duplicate, and results were expressed as $\mathrm{mg} / \mathrm{kg}$ sample (fresh weight).

\section{Questionnaire}

Restaurant managers were interviewed about the technical characteristics of frying operations. However, due to the confidentiality agreement signed with them, some details of the internal operating procedures cannot be displayed. Regarding school canteens, food operators filled out a questionnaire in order to evaluate cooking practices, specifically those for battering and breading intended for frying. Questions were structured according to check boxes with unique or multiple possible answers. The questionnaire was divided into five different themes. These were i) frying oil and frying appliance, ii) prefrying stage, iv) frying stage, and v) postfrying stage. All participants agreed for their data to be used in the present study.

\section{Statistical analysis}

Statistical analyses were performed using SPSS version 23.0 (SPSS Inc., Chicago, IL). Student t-tests and analysis of variance (ANOVA oneway) followed by Fisher's test calculations were used to identify the overall significance of differences between variables. Homogeneity of variances was determined using Levene's test. Relationships between the different variables were evaluated by computing Spearman's linear correlation coefficients. All statistical parameters were evaluated at the significance level of $p<0.05$.

\section{RESULTS AND DISCUSSION}




\section{Cooking practices in restaurants and primary school canteens}

Table I describes some cooking practices for the frying of battered and breaded products in restaurants and primary school canteens. Information provided by restaurant managers indicated that all restaurants used high oleic sunflower oil, with most using pre-established reference frying temperatures slightly above $175^{\circ} \mathrm{C}$ and with frying time automatically controlled. Both electric and gas fryers with a volume of at least II $L$ were used. All participating restaurants followed internal guidelines for frying, with only two having dedicated personnel for frying operations.

In the case of school canteens, food operators filled out an ad-hoc questionnaire for cooking practices (Table I). The survey showed that most operators used sunflower oil (92\%) and electric deep fryers (88\%). Only $28 \%$ of participants defrosted the par-fried product before frying and $64 \%$ followed recommendations provided on the products labeling. Most operators (88\%) controlled the temperature of the process to some extent, mainly by using the thermostat on the electric fryer (91\%). A quantity of food that was equivalent to half of the surface of the frying appliance (64\%) was usually fried per batch. Regarding post-frying operations, operators considered color to be the main criterion to determine the end-point of frying (64\%) and preferred fried food to be light-brown in color $(96 \%)$. Strainer (52\%) and absorbent papers (32\%) were mainly used to remove excess oil from the fried food. $52 \%$ of operators cleaned the oil by filtering it with a strainer and usually replaced oil after a non-specified number of frying cycles $(52 \%)$, or when the oil turned dark in color (36\%).

\section{Process contaminants in coated fried foods}

One-hundred and thirteen samples of coated fried foods from restaurants and school canteens and their respective crusts were analyzed for acrylamide, HMF and furfural. Sampling included the most representative variety of breaded and battered foods on the menu of food services, and covered meat-products (ham \& cheese and chicken nuggets), fish-products (fish sticks, fish fillets), seafood (squid rings), vegetables (onion rings) and doughs (croquettes) (Table SI). Most of the samples were breaded $(n=105)$. Amongst the battered samples $(n=8)$, two were squid rings and six were onion rings. Most of the samples $(78 \%)$ were frozen parfried foods (industrial source), except chicken nuggets and fish fillets coming from school canteens, which were prepared home-style by the operators.

Table 2 summarizes the content of acrylamide, HMF and furfural in the overall sample of coated fried food. Acrylamide ranged from $24 \mu \mathrm{g} / \mathrm{kg}$ to $130 \mu \mathrm{g} / \mathrm{kg}$, with a mean and median of $44 \mu \mathrm{g} / \mathrm{kg}$ and $34 \mu \mathrm{g} / \mathrm{kg}$, respectively. Onions rings exhibited the highest acrylamide content $(3 \mid 4 \mu \mathrm{g} / \mathrm{kg})$ of the coated fried foods. Half of the onion rings were battered and half were breaded but significant differences were not observed between them. Mean acrylamide content in chicken nuggets $(40 \mu \mathrm{g} / \mathrm{kg})$ was close to croquettes $(36 \mu \mathrm{g} / \mathrm{kg})$, squid rings $(36 \mu \mathrm{g} / \mathrm{kg})$ and ham \& cheese $(32 \mu \mathrm{g} / \mathrm{kg})$, whereas fish sticks $(25 \mu \mathrm{g} / \mathrm{kg})$ and fish fillets $(24 \mu \mathrm{g} / \mathrm{kg})$ showed the lowest acrylamide level. A similar pattern was observed for HMF and furfural. HMF ranged from $0.1 \mathrm{I}$ to 16.07 and furfural from 0.01 to $1.04 \mathrm{mg} / \mathrm{kg}$. The mean and median content was $1.98 \mathrm{mg} / \mathrm{kg}$ and $1.03 \mathrm{mg} / \mathrm{kg}$ for HMF and $0.17 \mathrm{mg} / \mathrm{kg}$ and $0.10 \mathrm{mg} / \mathrm{kg}$ for furfural, respectively. Again, onion rings exhibited the highest concentrations of HMF $(7.60 \mathrm{mg} / \mathrm{kg})$ and furfural $(0.43 \mathrm{mg} / \mathrm{kg})$, with significant differences in respect to the rest of the coated fried foods, which ranged between $0.50 \mathrm{mg} / \mathrm{kg}$ (squid rings) and $1.77 \mathrm{mg} / \mathrm{kg}$ (croquettes) for HMF, and between $0.06 \mathrm{mg} / \mathrm{kg}$ (breaded ham \& cheese) and $0.22 \mathrm{mg} / \mathrm{kg}$ (chicken nuggets) for furfural (Table 2).

The relationship amongst the different heat-induced process contaminants was investigated via bivariate correlations analysis. Results were expressed as Spearman correlation coefficients following the procedure for non-parametric variables. Significant correlations were found between acrylamide and HMF $(\rho=0.560$, P 
$<0.00 \mathrm{I})$, acrylamide and furfural $(\rho=0.548, \mathrm{p}<0.00 \mathrm{I})$, and HMF and furfural $(\rho=0.7 \mathrm{I}, \mathrm{p}<0.00 \mathrm{I})$. This significant and positive relationship corroborates the parallel progress of non-enzymatic browning reactions (Maillard reaction and caramelization). It also demonstrates the formation of acrylamide and furanic compounds in this randomized scenario of frying practices in food services, regardless of the type of coated food and type of coating material.

Results were in agreement with previous studies on battered and breaded products. Acrylamide content in this type of products from Norway, Sweden, Switzerland, the United Kingdom and the United States has been reported to be 30-39 $\mu \mathrm{g} / \mathrm{kg}$ in fish and seafood products and 39-64 $\mu \mathrm{g} / \mathrm{kg}$ in poultry (FAO/WHO, 2002). Concentrations lower than $100 \mu \mathrm{g} / \mathrm{kg}$ have been described in chicken nuggets (Eerola, Hollebekkers, Hallikainen, \& Peltonen, 2007; Sansano, Heredia, Peinado, \& Andrés, 2017), onion rings (Sansano et al., 2017) and in Japanese battered fried vegetables (tempura) (Ono et al., 2003). Survey data on acrylamide in food reported by the FDA in 2006 included concentrations of $103 \mu \mathrm{g} / \mathrm{kg}$ in breaded mushrooms and $93 \mu \mathrm{g} / \mathrm{kg}$ in breaded fried catfish, however acrylamide was not detected in deepfried breaded shrimp, fried breaded pork chops and chicken fingers (FDA, 2006). Individual values for battered foods were not described in the latest dataset reported by EFSA in 2015. This document included breaded meat, fish and vegetable products in 'other products based on cereals', where mean acrylamide concentration was set at $68 \mu \mathrm{g} / \mathrm{kg}$ (EFSA, 2015).

Pérez-Palacios et al. (2013) analyzed the content of the furanic compounds HMF and furfural in deep-fried and oven-baked breaded fish products, showing concentrations that ranged from $0.64 \mathrm{mg} / \mathrm{kg}$ to $4.47 \mathrm{mg} / \mathrm{kg}$ for $\mathrm{HMF}$ and from undetected levels to $0.57 \mathrm{mg} / \mathrm{kg}$ for furfural. These results agree with concentrations observed in the present study. Higher levels of HMF have recently been reported by Pérez-Burillo, Rufián-Henares, and Pastoriza (2019) in deep-fried breaded cauliflower $(88.9 \mathrm{mg} / \mathrm{kg})$ and eggplant $(103.5 \mathrm{mg} / \mathrm{kg})$.

The formation of process contaminants in coated fried foods mainly takes place in the crust. This makes the product crispy, with enticing aromas and visual appeal (Tamsen et al., 2018). This formation will depend on the composition of the coating. The coating may be formulated by breadcrumbs or flour, with or without the addition of water, milk, egg, salt, potato starch and seasonings, and shortenings, amongst other ingredients (Perera \& Embuscado, 2014). The type of coating material and its composition will contribute to levels of reducing sugars and amino acids, these being precursors of heat-induced contaminants. To get more insight into the fate of acrylamide, HMF and furfural in coated fried foods, the crust of the fried product was further studied. As expected, presence of heat-induced process contaminants in the coating material of the fried foods was higher than in the entire food (Fig. I). The highest amount was observed in the coating material of the onion ring food group, reaching values of up to $370 \mu \mathrm{g} / \mathrm{kg}$ for acrylamide, $11.95 \mathrm{mg} / \mathrm{kg}$ for HMF and $0.73 \mathrm{mg} / \mathrm{kg}$ for furfural. The rest of the food groups showed decreasing amounts of acrylamide, in the order of croquettes $(\mathrm{I} 3 \mathrm{I} \mu \mathrm{g} / \mathrm{kg})>$ fish fillets $(99.5 \mu \mathrm{g} / \mathrm{kg})>$ chicken nuggets $(93.0 \mu \mathrm{g} / \mathrm{kg})$. For HMF, decreasing amounts were seen in the order of fish sticks $(11.67 \mathrm{mg} / \mathrm{kg})>$ chicken nuggets $(8.97 \mathrm{mg} / \mathrm{kg})>$ croquettes $(6.68 \mathrm{mg} / \mathrm{kg})$. Finally, for furfural the order was fish sticks $(0.71 \mathrm{mg} / \mathrm{kg})>$ croquettes $(0.64 \mathrm{mg} / \mathrm{kg})>$ chicken nuggets $(0.56 \mathrm{mg} / \mathrm{kg})$. Although technical information about the composition of the coating material was unknown, the variability seen within the same food group is likely related to differences in the formulations and complexity of the layer of the coating material, independent of the frying conditions.

Protein content and amino acid composition differs within cereal varieties and, consequently, the type of flour used will drastically condition the formation of heat-induced process contaminants from non-enzymatic browning reactions. For example, it is known that corn and rice are grains with a low presence of asparagine (Muttucumaru et al., 2008). This fact supports the reduced acrylamide formation seen during heat treatment 
of foods containing this kind of cereals since asparagine content is considered to be the limiting factor for acrylamide formation in cereal products (Amrein, Schönbächler, Escher, \& Amadó, 2004). In line with this statement, Shih, Boué, Daigle, and Shih (2004) recommended the use of rice flour in the formulation of batters in order to minimize the acrylamide content in battered fried products. In contrast, higher asparagine levels have been reported in rye $(322 \mathrm{mg} / \mathrm{kg})$, spelt $(173 \mathrm{mg} / \mathrm{kg})$ and wheat flour (78 mg/kg) (Przygodzka et al., 20I5). At this respect, Barutcu, Sahin, and Sumnu (2009) reported that the formation of acrylamide in coating parts of chicken during microwave frying was lower when rice flour was used in the cover, as compared with results observed in batters containing chickpea or soy flour.

Breadcrumb coating derives from bread that is dried and custom grinded to form smaller sized particles. In a previous study, our research group analyzed five samples of breadcrumbs used for the coat batter of breaded foods (Mesias, Holgado, Márquez-Ruiz, \& Morales, 2016). Samples were characterized to estimate precursor content and other parameters involved in the development of process contaminants. Breadcrumbs were deep fried and levels of acrylamide, HMF and furfural were determined. Results showed variability for acrylamide $(78-538 \mu \mathrm{g} / \mathrm{kg})$, HMF $(7.8-95.5 \mathrm{mg} / \mathrm{kg})$ and furfural $(3.7-10.4 \mathrm{mg} / \mathrm{kg})$, which was related to difference in moisture, water activity, $\mathrm{pH}$, protein, reducing sugars and asparagine in breadcrumbs before frying. These factors directly influence the formation of Maillard reaction products (Friedman, 1996). Results exceeded those obtained in the present study. Nevertheless, they cannot be directly compared since only the coat layer was deep-fried in the Mesias et al. (2016) study and, consequently, the influence of the food matrix on breadcrumb behavior during frying was not considered. In addition, in the first experiment the frying process was carried out under controlled conditions, whereas processing conditions for samples of the present study were random and different. This makes comparisons between the two studies even more challenging. Another parameter to take into account is the thickness of the breading. In this sense, Guerra-Hernández, PlataGuerrero, and García-Villanova Ruiz (20I3) described large differences in acrylamide content when breaded vegetables were formulated with coarse $(219 \mu \mathrm{g} / \mathrm{kg})$ or fine breadcrumbs $(50 \mu \mathrm{g} / \mathrm{kg})$.

The protein contribution from milk and egg must be also considered, as well as the moisture provided by these ingredients to the final product. This is important since an inverse and significant relationship between moisture content and acrylamide concentration has been observed in battered foods (Guerra-Hernandez et al., 2016). On the other hand, egg has been traditionally considered a source of Sulphur amino acids, especially egg white (WHO, 1985). Michael addition reactions between sulphur amino acid and acrylamide could take place (Hamzalıoğlu \& Gökmen, 20I5) which, together with the moisture content, could explain the lower acrylamide detected in breaded foods which contain egg in their formulation (Guerra-Hernández et al., 20I3). In contrast, Paleologos and Kontoninas (2007) described extremely high levels of acrylamide (910-970 $\mu \mathrm{g} / \mathrm{kg})$ in fried and baked breaded chicken samples dipped in a batter of beaten eggs, spices and breadcrumbs. These authors suggested that, together with the processing conditions, the interaction between the carbohydrates from the breadcrumb and the free amino acids from both the egg and the chicken meat, promoted acrylamide formation.

Most battered and breaded foods analyzed in the present study were industrial products (frozen par-fried foods), aside from the fish fillets and chicken nuggets which were both provided by school canteens. Fish fillets, chicken nuggets and croquettes presented the lowest proportion of coating (20-27\%). The food group of fish fillets was found only in school canteens, whereas chicken nuggets were from both restaurants (industrial origin) and school canteens (home-style). In the food group of chicken nuggets, levels of heat-induced process contaminants were lower in school canteens in comparison to restaurants. Mean acrylamide content significantly increased from $22 \mu \mathrm{g} / \mathrm{kg}$ to $43 \mu \mathrm{g} / \mathrm{kg}$, HMF from I.12 to $1.55 \mathrm{mg} / \mathrm{kg}$ and furfural from 0.18 to 0.23 
$\mathrm{mg} / \mathrm{kg}$ in homestyle and industrial nuggets, respectively (Fig. 2). The contribution of coating in chicken nuggets was similar when their origin was industrial $(27 \%)$ or home-style $(26 \%)$ and, therefore, differences in process contaminant content could not be linked to the higher presence of crust in the fried product. Thus, the coating composition (that depends on the origin of the samples i.e. industrial vs. home-style), together with culinary practices, could be responsible for such differences. Commercial battered and breaded foods usually contain one or various foodstuffs of animal or vegetable origin, with the addition of flour and/or breadcrumbs, milk, egg, and other authorized substances, such as leavening agents and flavorings (seasoned as appropriate). These products are briefly fried and then frozen until later frying (Barbut, 20I5; Guerra-Hernández, 2016). Depending on the formulation, three types of batter can be recognized: adhesion batters, designed to adhere to food; cohesion batters, designed to form a shell around the product; and tempura batters, used to create a puffed texture around the food (Barbut, 20I5). In contrast, home-style preparation of battered foods generally consists of simply dipping slices of food in dry flour, followed by a quick dip in an egg batter and breadcrumbs to cover both sides (Barbut, 20I5). Foods are then prepared and are ready to fry in a short period. With such a simple formulation, the variability in the composition is low, leading to more controlled concentrations of acrylamide, HMF and furfural. This is typically characteristic of home-style foods. In contrast, more complex formulations of industrial batters may contain ingredients that promote the formation of Maillard reaction products. In this sense, leavening agents which are usually added to the raw breading ingredients (Barbut, 20I5) are known to strongly influence acrylamide formation (Amrein et al., 2004). Other ingredients are also added with the aim of enhancing the degree of browning during frying. Such is the case with caramel ingredients which are often used to obtain a distinctly darker shade (Barbut, 20I5), or the addition of proteins and reducing sugars (e.g. dextrose), which may contribute to a higher content of furfural compounds and enhance the extent of the non-enzymatic browning reaction.

Fish sticks, squid rings and onion rings did not present significant differences in the content of heat-induced process contaminants in the coat and the entire food. This fact may be due to the high proportion of crust in the entire food, which contributed to $59-61 \%$ of the overall food in the samples. Amongst these, onion rings presented the smallest difference in levels analyzed in the crust and the complete product (Fig. I). This observation could be explained by the high proportion of coating material ( $59 \%$ of the total weight) relative to the entire food. Onion is a bulb rich in amino acids and reducing sugars (Bogevska, Agic, Popsimonova, Davitkovska, \& Iljovsk, 2016; Hansen, 200I). As a result, the Maillard reaction may be enhanced during the frying process. Rufián-Henares, García-Villanova, and Guerra-Hernández (2008) detected HMF in dehydrated onion $(0.37 \mathrm{mg} / \mathrm{kg}$ ) and values of acrylamide close to $340 \mu \mathrm{g} / \mathrm{kg}$ have been reported in onion chips (Khan, Alothman, Naushad, Alomary, \& Alfadul, 2018). Yoshida, Isamu, and Chiku (2017) determined the content of acrylamide in 60 samples of stir-fried onions (not battered products) and described levels up to $420 \mu g / \mathrm{kg}$ with a mean content of $36 \mu \mathrm{g} / \mathrm{kg}$. Similar findings have been reported in other vegetables and roots subjected to thermal treatments (Mesias, Delgado-Andrade \& Morales, 2019).

Although food composition could directly affect process contaminant concentrations in the fried samples used in the present randomized scenario examining food handler practices during the preparation of battered and breaded foods, specific processing conditions in the different restaurants and school canteens might contribute as well. It is important to mention that randomized observational studies do not provide complete information since it is not possible to know and control all the factors which affect the results. Similar limitations have been suggested in other studies evaluating the formation of process contaminants in fried foods and their relationship with different culinary practices (Mesias, Delgado-Andrade, Holgado, \& Morales, 20I8; Mesias, Delgado-Andrade, Holgado, \& Morales, 2019; Sanny, Jinap, Bakker, van Boekel, \& Luning, 20I2). In the present trial, foods were deep-fried in high oleic sunflower oil (100\% from restaurants) and in sunflower oil ( $92 \%$ from 
school canteens), all of them using an electric deep fryer or frying pan (Table I). The use of different frying appliances did not significantly influence the development of compounds, neither did whether or not frying recommendations were followed, defrosting prior to the frying process, or temperature control. It could be suggested that both the frying conditions and the ingredients used in the formulation of breadcrumbs are critical to the formation of harmful compounds in the crust of battered and breaded products.

\section{CONCLUSIONS}

The occurrence of acrylamide, hydroxymethylfurfural and furfural was investigated following a randomized sampling scheme in five food groups (meat, fish, seafood, vegetable, and doughs), belonging to battered and breaded fried foods, provided by public food services such as restaurants and school canteens. This study contains some limitations derived from the confidentiality agreement signed with the food service establishments, which did not allow a detailed description of internal procedures for frying, and from the accessibility of information of the unprocessed foods and the coating materials. Even so, this is the first time that a systematic prospective evaluation of these compounds in real operating conditions at food services has been carried out in Spain, that is highly valuable for the calculation of exposure assessment to population.

Heat-induced process contaminants derived from non-enzymatic browning reactions were detected in all of the coated fried foods with a mean content of $44 \mu \mathrm{g} / \mathrm{kg}$ (II-3I4; min-max), $1.98 \mathrm{mg} / \mathrm{kg}(0.1 \mathrm{I}-16.07$; min$\max )$, and $0.17 \mathrm{mg} / \mathrm{kg}(0.01-1.04 ;$ min-max) for acrylamide, HMF and furfural, respectively. As expected, results confirm that the occurrence of process contaminants is higher in the crust of coated fried foods since non-enzymatic browning reactions proceed from the outer part of the food to the core. Concerning acrylamide as a regulated process contaminant, battered and breaded onion rings exhibited highest concentrations ( $130 \mu \mathrm{g} / \mathrm{kg}$ ) with significant differences relative to other food groups. It was noteworthy that acrylamide content in home-style prepared chicken nuggets was significantly lower than in chicken nuggets prepared from frozen par-fried samples. Furthermore, the composition and complexity of the coating material, alongside the extent of frying, could greatly influence the extent of the reaction leading to heat-induced process contaminants. As a consequence, side effects related to the presence of process contaminants in battered and breaded fried foods should be carefully considered. Although the recent Regulation for acrylamide does not mention specific values or mitigation strategies for battered and breaded products, the contribution of these foods to daily acrylamide exposure must not be dismissed.

\section{CRediT authorship contribution statement}

Marta Mesias: Conceptualization, Data curation, Formal analysis, Investigation, Methodology, Software, Validation, Writing - original draft, Writing - review \& editing. Cristina Delgado-Andrade: Conceptualization, Data curation, Investigation, Supervision, Validation, Visualization, Writing - review \& editing. Francisco J. Morales: Conceptualization, Data curation, Funding acquisition, Investigation, Project administration, Resources, Supervision, Validation, Visualization, Writing - review \& editing.

\section{Declaration of competing interest}

The authors declare that they have no conflict of interest.

\section{Acknowledgments}

This research was partly funded by the Ministry of Economy and Competitiveness (Spain) under the projects SAFEFRYING (AGL2015-46234-R; MINECO) and ACRINTAKE (RTI2018-094402-B-100, MCIU/AEI/FEDER, UE). The authors thank Ms. I. Alvarez and Ms. B. Díaz for their technical assistance, the Spanish Association 'Marcas de Restauración' for assistance in the recruitment of restaurants, school canteens for their 
participation, and to the staff of the General Directorate for Public Health of the Autonomous Community of Castilla-La Mancha (Spain) for the sampling and coordination of primary schools through its Food Health Service.

\section{Appendix A. Supplementary data}

Supplementary data to this article can be found online at https://doi.org/10.1016/j.foodcont.2020.107217.

\section{REFERENCES}

AECOSAN (Agencia Española de Seguridad Alimentaria) (2005). Estrategia para la nutrición, actividad física y prevención de la obesidad (NAOS). Invertir la tendencia de la obesidad. Madrid: Agencia Española de Seguridad Alimentaria.

AESAN (Agencia Española de Seguridad Alimentaria y Nutrición). http://www.aecosan.msssi.gob.es/AECOSAN/web/seguridad_alimentaria/subdetalle/enalia.htm/ Accessed 7 October 2019.

Albert, Á., Salvador, A., Hough, G., \& Fiszman, S. (2013). Influence of outer layer formulation on the sensory properties of microwaved breaded nuggets. International Journal of Food Properties, 17, 829-84I.

Alburquerque, T. G., Oliveira, M. A. P. P., Sanches-Silva, A., Bento, A. C., \& Costa, H. S. (2016). The impact of cooking methods in the nutritional quality and safety of chicken breaded nuggets. Food \& Function, 7 , 2736-2746.

Amrein, T. M., Schönbächler, B., Escher, F., \& Amadó, R. (2004). Acrylamide in gingerbread: Critical factors for formation and possible ways for reduction. Journal of Agricultural and Food Chemistry, 52, 42824288.

Barbut, S. (2015). Battering and breading. Production under HACCP. The science of poultry and meat processingGuelph, Ontario, Canada: University of Guelph (Chapter 14).

Barutcu, I., Sahin, S., \& Sumnu, G. (2009). Acrylamide formation in different batter formulations during microwave frying. Lebensmittel-Wissenschaft und -Technologie-Food Science and Technology, 42, I722.

Bogevska, Z., Agic, R., Popsimonova, G., Davitkovska, M., \& Iljovsk, I. (2016). Reducing and total sugar content in onion during storage in the Republic of Macedonia. Agroknowledge Journal, 17, 37-46.

Brannan, R. G., Mah, E., Schott, M., Yuan, S., Casher, K. L., Myers, A., et al. (20I4). Influence of ingredients that reduce oil absorption during immersion frying of battered and breaded foods. European Journal of Lipid Science and Technology, I 16, 240-254.

Capuano, E., \& Fogliano, V. (20I I). Acrylamide and 5-hydroxymethylfurfural (HMF): A review on metabolism, toxicity, occurrence in food and mitigation strategies. LWT - Food Science and Technology (Lebensmittel-Wissenschaft und -Technologie), 44, 793-810.

EC (European Commission) (2017). Commission Regulation (EU) 2017/2I58 of 20 November 2017 establishing mitigation measures and benchmark levels for the reduction of the presence of acrylamide in food. Official Journal of the European Union, L304, 24-44.

Eerola, S., Hollebekkers, K., Hallikainen, A., \& Peltonen, K. (2007). Acrylamide levels in Finnish foodstuffs analysed with liquid chromatography tandem mass spectrometry. Molecular Nutrition \& Food Research, 5I, 239-247.

EFSA (European Food Safety Authority) (2005). Opinion of the scientific panel on food additives, flavourings, processing aids and materials in contact with food on a request from the commission related to furfural and furfural diethylacetal. EFSA Journal, 61, I-27.

EFSA (European Food Safety Authority) (2015). Scientific opinion on acrylamide in food. EFSA Journal, I3(6), 4104. 
FAO/WHO (2002). Health implications of acrylamide in food. Report of a Joint FAO/WHOConsultationGeneva: WHO.

FDA (U.S. Food and Drug Administration). (2006). Center for food safety and applied nutrition. https://www.fda.gov/food/chemicals/acrylamide/ Accessed 10 October 2019.

FDE (Food Drink Europe) (2019). The acrylamide toolbox. https://www.fooddrinkeurope. eu/uploads/publications_documents/FoodDrinkEurope_Acrylamide_Toolbox_2019.pdf/ Accessed 20 September 2019.

Friedman, M. (1996). Food browning and its prevention: an overview. Journal of Agricultural and Food Chemistry, 44, 631-653.

Gilbert, P. A., \& Khokhar, S. (2008). Changing dietary habits of ethnic groups in Europe and implications for health. Nutrition Reviews, 66, 203-215.

Glatt, H., Schneider, H., \& Liu, Y. (2005). V79-hCYP2EI-hSULTIAI, a cell line for the sensitive detection of genotoxic effects induced by carbohydrate pyrolysis products and other food-borne chemicals. Mutation Research: Genetic Toxicology and Environmental Mutagenesis, 580, 4I-52.

Guerra-Hernández, E. (2016). Acrylamide in battered foods. In V. Gökmen (Ed.). Acrylamide in Food. Analysis, content and potential health effects (pp. 253-274). Oxford, UK: Academic Press.

Guerra-Hernández, E., Plata-Guerrero, R., \& García-Villanova Ruiz, B. (20/3). Acrylamide formation in different batter and breading formulation during deep-frying of zucchini and exposure estimation. Annals of Nutrition and Metabolism, 184I, 63.

Hamzalıoglu, A., \& Gökmen, V. (2015). Investigation of the reactions of acrylamide during in vitro multistep enzymatic digestion of thermally processed foods. Food \& Function, 6, 109-II4.

Hansen, S. L. (200I). Content of free amino acids in onion (Allium cepa L.) as influenced by the stage of development at harvest and long-term storage. Acta Agriculturae Scandinavica Section B Soil and Plant Science, 5I, 77-83.

Høie, A. H., Svendsen, C., Brunborg, G., Glatt, H., Alexander, J., Meinl, W., et al. (20I5). Genotoxicity of three food processing contaminants in transgenic mice expressing human sulfotransferases IAI and IA2 as assessed by the in vivo alkaline single cell gel electrophoresis assay. Environmental and Molecular Mutagenesis, 56, 709-714.

Khan, M. R., Alothman, Z. A., Naushad, M., Alomary, A. K., \& Alfadul, S. M. (2018). Monitoring of acrylamide carcinogen in selected heat-treated foods from Saudi Arabia. Food Science and Biotechnology, 27, 1209 1217.

Lazarick, K., Aladedunye, F., \& Przybylski, R. (20/4). Effect of breading and battering ingredients on performance of frying oils. European Journal of Lipid Science and Technology, I 16, 763-770.

Lee, C. H., Chen, K. T., Lin, J. A., Chen, Y. T., Chen, Y. A., Wu, J. T., et al. (2019). Recent advances in processing technology to reduce 5-hydroxymethylfurfural in foods. Trends in Food Science \& Technology, 93, 27I280.

Loewe, R. (20I I). Ingredient selection for batter and breading systems. In K. Kulp, R. Loewe, K. Lorenz, \& J. Gelroth (Eds.). Batters and breadings in food processing (pp. 9-24). St. Paul, Minnesota, USA: American Associate of Cereal Chemists International (AACC).

Mallikarjunan, K., Ngadi, M. O., \& Chinnan, M. S. (2010). Batter and breading: Classification and processing systems. In P. K. Mallikarjunan, M. O. Ngadi, \& M. S. Chinnan (Eds.). Breaded fried foods (pp. 8I-96). Boca Raton, FL, USA: CRC Press Taylor \& Francis group.

Maskat, M. Y., \& Kerr, W. L. (2002). Coating characteristics of fried chicken breasts prepared with different particle size breading. Journal of Food Processing and Preservation, 26, 27-38.

Mesias, M., Delgado-Andrade, C., Holgado, F., \& Morales, F. J. (2018). Acrylamide content in French fries prepared in households: A pilot study in Spanish homes. Food Chemistry, 260, 44-52. 
Mesias, M., Delgado-Andrade, C., Holgado, F., \& Morales, F. J. (2019). Acrylamide content in French fries prepared in food service establishments. LWT - Food Science and Technology (LebensmittelWissenschaft und -Technologie), 100, 83-91.

Mesias, M., Delgado-Andrade, C., \& Morales, F. J. (2019). Alternative food matrices for snack formulations in terms of acrylamide formation and mitigation. Journal of the Science of Food and Agriculture, 99, 20482051 .

Mesias, M., Holgado, F., Marquez-Ruiz, G., \& Morales, F. J. (20I5). Effect of sodium replacement in cookies on the formation of process contaminants and lipid oxidation. LWT - Food Science and Technology (Lebensmittel-Wissenschaft und -Technologie), 62, 633-639.

Mesias, M., Holgado, F., Márquez-Ruiz, G., \& Morales, F. J. (20I6). An investigation of process contaminants' formation during the deep frying of breadcrumbs using a bread coat model. Food \& Function, 7, 16451654.

Mesias, M., \& Morales, F. J. (20I5). Acrylamide in commercial potato crisps from Spanish market: Trends from 2004 to 2014 and assessment of the dietary exposure. Food and Chemical Toxicology, 8I, I04-II0.

Morales, F. J. (2008). Hydroxymethylfurfural (HMF) and related compounds. In R. H. Stadler, \& D. R. Lineback (Eds.). Process-induced food toxicants: Occurrence, formation, mitigation, and health risks (pp. 135174). New Jersey, USA: John Wiley \& Sons, Inc.

Morales, F. J., \& Arribas-Lorenzo, G. (2008). The formation of potentially harmful compounds in churros, a Spanish fried-dough pastry, as influenced by deep frying conditions. Food Chemistry, 109, 42I-425.

Muttucumaru, N., Elmore, J. S., Curtis, T., Mottram, D. S., Parry, M. A. J., \& Halford, A. G. (2008). Reducing acrylamide precursors in raw materials derived from wheat and potato. Journal of Agricultural and Food Chemistry, 56, 6167-6172.

Ono, H., Chuda, Y., Ohnishi-Kameyama, M., Yada, H., Ishizaka, M., Kobayashi, H., et al. (2003). Analysis of acrylamide by LC-MS/MS and GC-MS in processed Japanese food. Food Additives \& Contaminants, 20, 215-220.

Paleologos, E. K., \& Kontoninas, M. G. (2007). Effect of processing and storage conditions on the generation of acrylamide in precooked breaded chicken products. Journal of Food Protection, 70, 466-470.

Perera, C., \& Embuscado, M. E. (2014). Texture design for breaded and battered foods. In Y. L. Dar, \& J. M. Light (Eds.). Food Texture design and optimization (pp. 128-158). Chicago, IL: John Wiley \& Sons.

Pérez-Burillo, S., Rufián-Henares, J. A., \& Pastoriza, S. (2019). Effect of home cooking on the antioxidant capacity of vegetables: Relationship with Maillard reaction indicators. Food Research International, I2I, 514-523.

Pérez-Palacios, T., Petisca, C., Henriques, R., \& Ferreira, I. M. (20I3). Impact of cooking and handling conditions on furanic compounds in breaded fish products. Food and Chemical Toxicology, 55, 222-228.

Przygodzka, M., Piskula, M. K., Kukurová, K., Ciesarová, Z., Bednarikova, A., \& Zielinski, H. (20I5). Factor influencing Acrylamide formation in rye, wheat and spelt breads. Journal of Cereal Science, 65, 96-102.

Rufián-Henares, J. A., García-Villanova, B., \& Guerra-Hernández, E. (2008). Occurrence of furosine and hydroxymethylfurfural as markers of thermal damage in dehydrated vegetables. European Food Research and Technology, 228, 249-256.

Sanny, M., Jinap, S., Bakker, E. J., van Boekel, M. A. J. S., \& Luning, P. A. (2012). Possible causes of variation in acrylamide concentration in French fries prepared in food service establishments: An observational study. Food Chemistry, 132, I34-143.

Sansano, M., Heredia, A., Peinado, I., \& Andrés, A. (2017). Dietary acrylamide: What happens during digestion. Food Chemistry, 237, 58-64.

Shih, F. F., Boué, S. M., Daigle, K. W., \& Shih, B. Y. (2004). Effects of flour sources on acrylamide formation and oil uptake in fried batters. Journal of the American Oil Chemists' Society, 8I, 265-268. 
Suderman, D. R. (20II). Effective use of flavorings and seasonings in batter and breading systems. In K. Kulp, R. Loewe, K. Lorenz, \& J. Gelroth (Eds.). Batters and breadings in food processing (pp. 73-90). St. Paul, Minnesota, USA: American Associate of Cereal Chemists International (AACC).

Tamsen, M., Soltanizadeh, N., \& Shekarchizadeh, H. (2018). Evaluation of physicochemical properties of chicken nugget produced with amaranth seed flour. Iranian Food Science and Technology Research Journal, 14, 755-765.

Varela-Moreiras, G., Ávila, J. M., Cuadrado, C., del Pozo, S., Ruiz, E., \& Moreiras, O. (2010). Evaluation of food consumption and dietary patterns in Spain by the food consumption survey: Updated information. European Journal of Clinical Nutrition, 64, S37-S43.

Villadiego, V., \& Castro, N. (2018). Radiografía del sector de la restauración escolar. In Del campo al Cole (Ed.). Los comedores escolares en España. Del diagnóstico a las propuestas de mejora (pp. 10-26). . http://www.ciudadesagroecologicas.eu/loscomedores-escolares-en-espana-del-diagnostico-a-laspropuestas-de-mejora// Accessed 5 October 2019.

WHO (World Health Organization) (1985). Energy and protein requirements (WHO technical report series, No.724). Report of a joint FAO/WHO/UNU expert consultation Geneva: World Health Organization.

Yoshida, M., Isamu, M., \& Chiku, K. (2017). Acrylamide in stir-fried potato and onion for simmered dishes in Japan. Food Safety, 5, 54-60. 
FIGURES AND TABLES

Table I

Description of cooking practices for the frying of coated products in restaurants and primary school canteens. Results are expressed as percentage of the operators.

\begin{tabular}{|c|c|c|c|c|}
\hline \multicolumn{5}{|l|}{ Restaurants } \\
\hline \multirow{2}{*}{ Frying oil } & HOSO & Other & & \\
\hline & 100 & 0 & & \\
\hline \multirow{2}{*}{ Heat source } & electric & gas & & \\
\hline & 60 & 40 & & \\
\hline \multirow{2}{*}{ Temp. $>175^{\circ} \mathrm{C}$} & yes & No & nd & \\
\hline & 40 & 40 & 20 & \\
\hline \multirow{2}{*}{ Timer } & yes & No & & \\
\hline & 80 & 20 & & \\
\hline \multirow{2}{*}{ Guidelines for frying } & yes & no & & \\
\hline & 100 & 0 & & \\
\hline \multirow{2}{*}{ Dedicated personnel } & Yes & No & & \\
\hline & 40 & 60 & & \\
\hline \multicolumn{5}{|l|}{ School Canteens } \\
\hline \multicolumn{5}{|l|}{ Frying oil and frying appliance } \\
\hline Frying oil & $\begin{array}{l}\text { sunflower oil } \\
92\end{array}$ & $\begin{array}{l}\text { other } \\
8\end{array}$ & & \\
\hline Frying appliance & $\begin{array}{l}\text { frying pan } \\
8\end{array}$ & $\begin{array}{l}\text { electric deep fryer } \\
88\end{array}$ & $\begin{array}{l}\text { both } \\
4\end{array}$ & \\
\hline \multicolumn{5}{|l|}{ Pre-frying } \\
\hline \multirow{2}{*}{ Defrost } & yes & no & missing & \\
\hline & 28 & 36 & 36 & \\
\hline \multicolumn{5}{|l|}{ Frying } \\
\hline \multirow{2}{*}{ Recommendations } & yes & no & & \\
\hline & 64 & 36 & & \\
\hline \multirow{2}{*}{ Temperature control } & yes & No & & \\
\hline & 88 & 12 & & \\
\hline Control measures & $\begin{array}{l}\text { thermostat } \\
91\end{array}$ & $\begin{array}{l}\text { smoke point } \\
9\end{array}$ & & \\
\hline \multirow{2}{*}{ Food/appliance surface } & $<$ half & half & $>$ half & full \\
\hline & 20 & 64 & 8 & 8 \\
\hline \multicolumn{5}{|l|}{ Post-frying } \\
\hline \multirow{2}{*}{ End-point criteria } & color & taste & timer & smell \\
\hline & 64 & 12 & 16 & 8 \\
\hline Color preference & $\begin{array}{l}\text { Lighter-brown } \\
96\end{array}$ & $\begin{array}{l}\text { Darker-brown } \\
4\end{array}$ & & \\
\hline \multirow{2}{*}{ Oil removal } & paper & strainer & both & none \\
\hline & 32 & 52 & 12 & 4 \\
\hline \multirow{2}{*}{ Oil cleaning } & strainer & grater & decantation & not reuse \\
\hline & 52 & 16 & 12 & 20 \\
\hline \multirow{2}{*}{ Oil replacement criteria } & frying cycles & dark color & strange taste & missing \\
\hline & 52 & 36 & 4 & 8 \\
\hline
\end{tabular}

HOSO: High oleic sunflower oil. nd: not described. 


\section{Table 2}

Average content of acrylamide $(\mu \mathrm{g} / \mathrm{kg})$, hydroxymethylfurfural $(\mathrm{HMF}, \mathrm{mg} / \mathrm{kg})$ and furfural $(\mathrm{mg} / \mathrm{kg})$ in coated fried foods.

\begin{tabular}{lccrcccc}
\hline & \multicolumn{3}{c}{ n } & Merylamide & \multicolumn{2}{c}{ HMF } & \multicolumn{2}{c}{ Furfural } \\
& & Mean & SD & Mean & SD & Mean & SD \\
\hline Breaded ham \& cheese & 16 & $32 \mathrm{ab}$ & 7.9 & $0.94 \mathrm{a}$ & 0.59 & $0.06 \mathrm{a}$ & 0.07 \\
Chicken nuggets & 42 & $40 \mathrm{~b}$ & 11.4 & $1.49 \mathrm{a}$ & 0.88 & $0.22 \mathrm{~b}$ & 0.17 \\
Fish sticks & 14 & $25 \mathrm{ab}$ & 4.2 & $1.96 \mathrm{a}$ & 2.15 & $0.13 \mathrm{ab}$ & 0.10 \\
Fish fillets & 19 & $24 \mathrm{a}$ & 13.1 & $0.63 \mathrm{a}$ & 0.97 & $0.07 \mathrm{a}$ & 0.07 \\
Squid rings & 2 & $36 \mathrm{ab}$ & 4.4 & $0.50 \mathrm{a}$ & 0.34 & $0.10 \mathrm{ab}$ & 0.01 \\
Onion rings & 12 & $130 \mathrm{c}$ & 79.6 & $7.60 \mathrm{~b}$ & 4.79 & $0.43 \mathrm{c}$ & 0.29 \\
Croquettes & 8 & $36 \mathrm{ab}$ & 19.9 & $1.77 \mathrm{a}$ & 1.66 & $0.11 \mathrm{ab}$ & 0.07 \\
\hline
\end{tabular}

SD: Standard deviation. Different letters in the same column mean significant differences between samples $(p<0.05)$. 
Figure I. Content of heat-induced process contaminants in the crust of coated fried foods prepared in restaurants $(n=60)$ and school canteens $(n=53)$. $(A)$ acrylamide $(\mu g / k g),(B)$ hydroxymethylfurfural $(\mathrm{mg} / \mathrm{kg})$ and $(C)$ furfural $(\mathrm{mg} / \mathrm{kg})$. Values are mean $\pm \mathrm{SD}$. Different letters in the same figure mean significant differences between samples $(p<0.05)$.

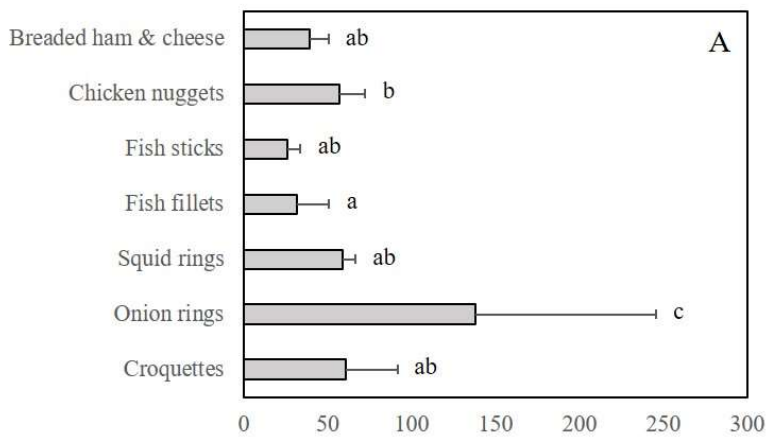

Acrylamide $(\mu \mathrm{g} / \mathrm{kg})$
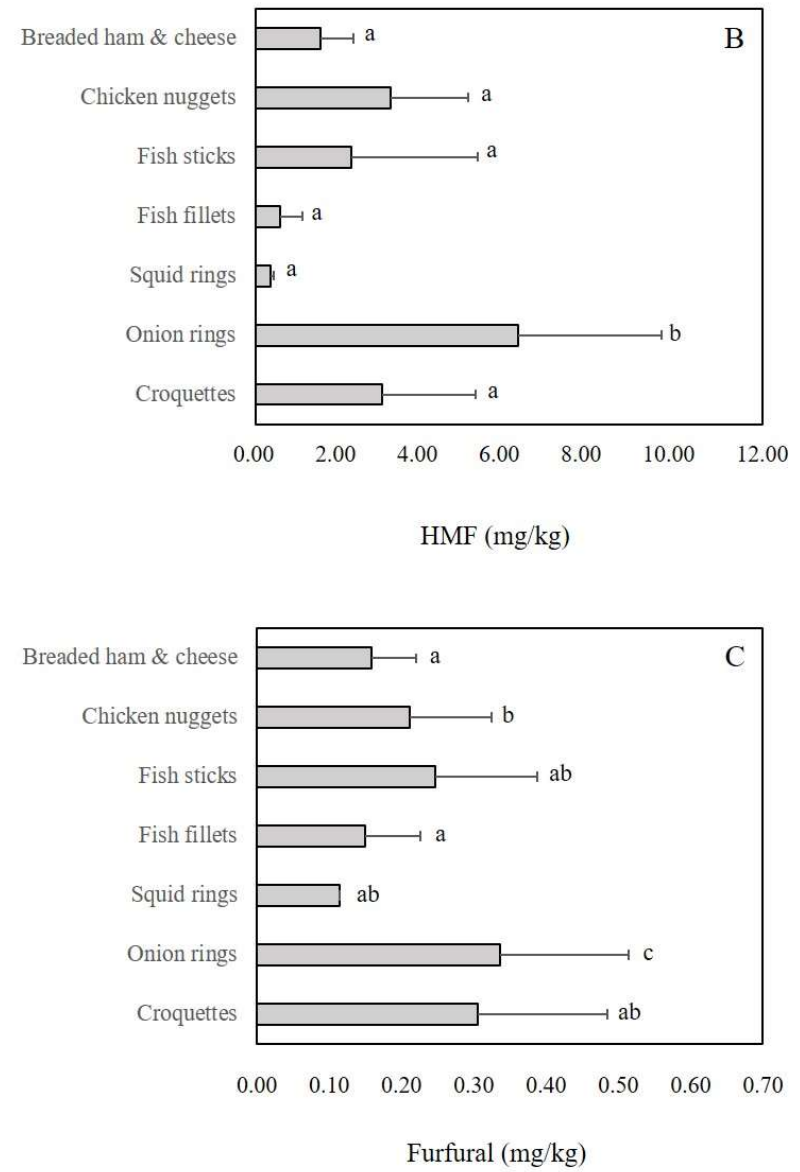

M. Mesías et al. / Food Control 2020, I 14, 107217 pag. 16 
Figure 2. Box-and-whisker plot for heat-induced process contaminant content in coated fried foods measured in fresh-prepared 'home-style' $(n=6)$ and frozen par-fried 'industrial' $(n=36)$ chicken nuggets. $(A)$ acrylamide $(\mu \mathrm{g} / \mathrm{kg})$, (B) hydroxymethylfurfural $(\mathrm{mg} / \mathrm{kg})$ and $(\mathrm{C})$ furfural $(\mathrm{mg} / \mathrm{kg})$. Values are mean $\pm \mathrm{SD}$. Different letters in the same figure mean significant differences between samples $(p<0.05)$.
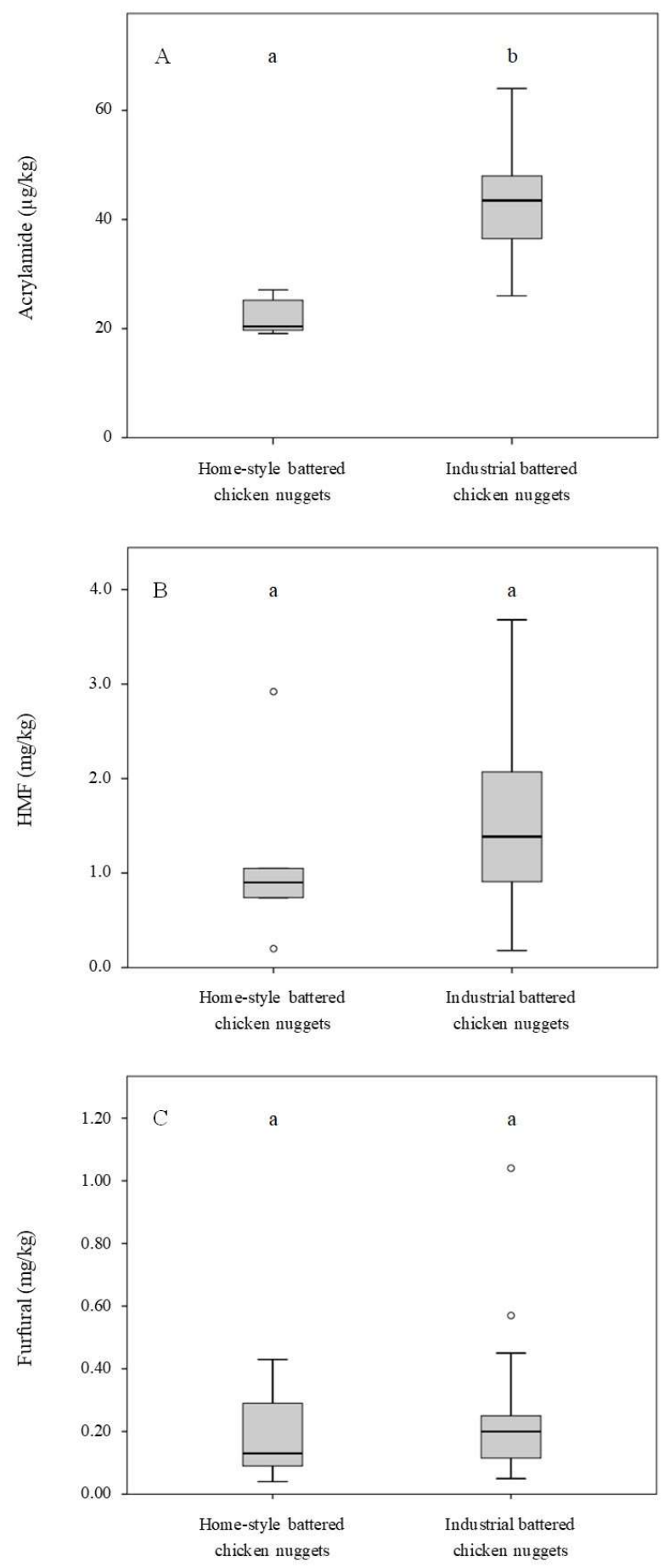


\section{SUPLEMMENTARY}

Table SI. Description of number and type of coated foods provided by restaurants and school canteens

\begin{tabular}{lcccc}
\hline Coated food & \multicolumn{2}{c}{ Restaurant } & \multicolumn{2}{c}{ School canteen } \\
& Battered & Breaded & Battered & Breaded \\
\hline Breaded ham \& cheese & - & 12 & - & 4 \\
Chicken nuggets & - & 36 & - & 6 \\
Fish sticks & - & - & - & 14 \\
Fish fillets & - & - & - & 19 \\
Squid rings & - & - & 2 & - \\
Onion rings & 6 & 6 & - & - \\
Croquettes & - & - & - & 8 \\
\hline
\end{tabular}

